\title{
EFISIENSI PEMASARAN BABI BALI DALAM RANGKA MENINGKATKAN PENDAPATAN PETANI DI DAERAH MARGINAL
}

\author{
SUKANATA, I W., I K. W. PARIMARTHA, DAN B. R .T. PUTRI \\ Fakultas Peternakan Universitas Udayana \\ e-mail: wayansukanata@unud.ac.id
}

\begin{abstract}
ABSTRAK
Penelitian ini di Kecamatan Gerokgak Kabupaten Buleleng, Kecamatan Abang Kabupaten Karangasem, dan Kecamatan Nusa Penida Kabupaten Klungkung, dari bulan Juni hingga Oktober 2018, dengan tujuan untuk menganalisis sejauh mana efisiensi pemasaran babi bali di daerah marginal. Jenis data yang digunakan adalah data kuantitatif dan data kualitatif yang bersumber dari data primer. Data dikumpulkan melalui observasi, wawancara, dan dokumentasi. Wawancara dilakukan terhadap 100 orang perternak, 20 orang pedagang perantara yang terdiri atas 5 penyotek (informan), 5 pengepul, 5 pedagang antar daerah, dan 5 pedagang pembuat babi guling. Efisiensi pemasaran dilihat dari struktur pasar, saluran pemasaran, farmer's share, margin pemasaran, dan rasio keuntungan terhadap biaya. Hasil penelitian ini menunjukkan bahwa sistem pemasaran babi bali yang dihasilkan di daerah penelitian kurang efisien. Ada empat saluran pemasaran babi bali dengan struktur pasar bersaing tidak sempurna (oligopsoni). Rata-rata farmer's share dari keempat saluran pemasaran hanya 61,41\%. Margin pemasaran diantara lembaga-lembaga pemasaran juga kurang merata, yaitu berkisar antara 0,94\%-37,5\% dari harga di konsumen. Rasio keuntungan terhadap biaya diantara lembaga-lembaga pemasaran mencapai $172,73 \%$ - 700\%, sedangkan yang dicapai peternak berkisar antara 15,16\%-24,02\%.
\end{abstract}

Kata kunci: babi bali, struktur pasar, saluran pemasaran, farmer's share, marjin pemasaran, dan rasio keuntungan terhadap biaya

\section{MARKETING EFFICIENCY OF BALI PIG IN ORDER TO INCREASE FARMERS' INCOME IN THE MARGINAL REGION}

\begin{abstract}
The research was conducted in Gerokgak, Abang, and Nusa Penida Districth from June to October 2018, with the aims to determine the marketing efficiency of bali pig. Types of data used were quantitative and qualitative data, which were sourced from the primary data. Data were collected through observation, interviews, and documentation. Interviews was conducted with 100 farmers, 20 middleman consisting of 5 "penyotek (informant)", 5 "pengepul (collectors)", 5 inter-regional traders, and 5 grilled pig producers. The marketing efficiency were determined by market structure, marketing chanel, farmer's share, marketing margin, and profit cost ratio. The results of this study indicate that the marketing system of bali pig is less efficient. There are four chanels in bali cattle marketing with imperpectly market structure (oligopsony). Average of the farmer's share from the fourt chanels are $61,41 \%$. While the marketing margin of the marketing agencies were uneven with the range of $0,94 \%-37,5 \%$ of the consumer price. The profit-cost ratio achieved by the marketing agencies are $172,73 \%-700 \%$, however, that achieved by farmers are an average of only $48.43 \%$.

Key words: bali pig, market structure, marketing chanel, farmer's share, marketing margin, profit cost ratio

\section{PENDAHULUAN}

Salah satu jenis babi yang banyak dipelihara di Bali adalah babi bali yang merupakan sumber flasma nutfah asli Bali. Babi bali memiliki berbagai keunggulan dibandingkan babi ras, seperti lebih tahan terhadap

lingkungan/cuaca yang ekstrim, dapat tumbuh dengan baik walaupun pakan yang diberikan seadanya, serta hemat air (Budaarsa, 1997). Keunggulan tersebut membuat babi jenis ini menjadi pilihan petani di daerah-daerah marginal, karena di daerah marginal masih mampu berproduksi dengan baik. Dengan pakan
\end{abstract}


yang baik babi bali mampu menghasilkan karkas ratarata 69,31\% (Wibawa, et al. 2019). Disamping itu, babi bali juga memiliki citarasa yang lebih gurih, dan sangat cocok dipakai sebagai babi guling (Budaarsa, 2012; 2014). Di beberapa daerah di Bali, dalam membuat babi guling untuk sesaji masih fanatik menggunakan babi bali.

Dalam beternak babi bali, aspek pemasaran sangat penting diperhatikan karena akan sangat mempengaruhi pendapatan peternak dan keberlanjutan dari usahatani itu. Keberhasilan dalam hal produksi tanpa memperhatikan masalah pemasaran belumlah cukup untuk menjamin tercapainya keuntungan. Sistem pemasaran yang lebih baik akan memberikan pendapatan yang lebih besar kepada peternak. Semakin efisien pemasaran maka pendapatan yang akan diperoleh peternak juga semakin tinggi dan sebaliknya.

Tujuan dilakukannya penelitian ini adalah untuk menganalisis efisiensi pemasaran babi bali di daerah marginal. Hasilnya diharapkan dapat membantu pemerintah dalam merumuskan kebijakan khususnya dalam hal pemasaran sehingga peternakan babi bali yang menjadi mata pencaharian masyarakat di daerah marginal akan lebih maju di masa yang akan datang.

\section{METODE PENELITIAN}

\section{Lokasi dan Waktu Penelitian}

Penelitian ini dilaksanakan sejak Bulan Juni hingga Oktober 2018 di Kecamatan Gerokgak Kabupaten Buleleng, Kecamatan Abang Kabupaten Karangasem, dan Kecamatan Nusa Penida Kabupaten Klungkung. Lokasi dipilih dengan sengaja dengan pertimbangan bahwa ketiga daerah tersebut merupakan basis peternakan babi bali.

\section{Jenis Data, Responden, dan Metode Pengumpulan Data}

Jenis data yang digunakan dalam penelitian ini berupa data kuantitatif dan kualitatif yang bersumber dari data primer. Data dikumpulkan dengan melakukan pengamatan, wawancara langsung terhadap responden dengan bantuan kuisioner, dan dokumentasi. Responden dalam penelitian ini terdiri atas; 100 orang perternak, 20 orang pedagang perantara (yang terdiri atas 5 penyotek (informan), 5 pengepul, 5 pedagang antar daerah, dan 5 pedagang pembuat babi guling. Penelusuran terhadap lembaga-lembaga pemasaran yang terlibat dilakukan dengan teknik snowball sampling.

\section{Pengolahan dan Analisis Data}

Data yang diperoleh dianalisis secara kualitatif dan kuantitatif. Efisiensi pemasaran babi bali ditentukan berdasarkan pendekatan struktur pasar, perilaku pasar, dan keragaan pasar. Analisis kualitatif dilakukan dengan mendeskripsikan struktur pasar, perilaku pasar, saluran pemasaran, dan lembaga pemasaran babi bali. Analisis kuantitatif digunakan untuk menganalisis margin pemasaran, farmer's share, dan rasio keuntungan terhadap biaya.

Margin pemasaran ditentukan dengan cara berikut (Sutarno, 2014).

$$
\mathrm{M}_{\mathrm{i}}=\mathrm{P}_{\mathrm{si}}-\mathrm{P}_{\mathrm{bi}}
$$

Keterangan:

$\mathrm{M}_{\mathrm{i}}=$ margin pemasaran pasar tingkat ke-i

$\mathrm{P}_{\mathrm{si}}=$ harga jual pasar di tingkat ke-i

$\mathrm{P}_{\mathrm{bi}}=$ harga beli pasar di tingkat ke-i

Sedangkan farmer's share ditentukan dengan cara sebagai berikut (Aditya, 2006):

$$
F_{s}=\frac{P_{p}}{P_{k}} \times 100 \%
$$

\section{Keterangan:}

FS = farmer's share

$\mathrm{Pp}=$ harga di tingkat peternak

$\mathrm{Pk}=$ harga yang dibayarkan oleh konsumen akhir

Rasio keuntungan terhadap biaya pada masingmasing lembaga pemasaran ditentukan dengan cara sebagai berikut (Jumiati, et al. 2013):

Rasio Keuntungan terhadap Biaya $=\frac{\mathrm{p}_{i}}{C_{i}} \times 100$

Keterangan:

$\pi \mathrm{i}=$ Keuntungan lembaga pemasaran ke- $\mathrm{i}$

$\mathrm{Ci}=$ Biaya pemasaran lembaga ke-i

\section{HASIL DAN PEMBAHASAN}

\section{Struktur Pasar Babi Bali (Market Structure)}

Babi bali yang dijual oleh peternak mempunyai karakteristik yang hampir sama. Babi yang dipasarkan umumnya adalah anak babi, babi muda maupun babi dewasa. Anak babi biasanya dipasarkan sebagai ternak bibit baik untuk penggemukan maupun induk. Pembelinya adalah peternak lainnya yang memelihara babi. Sedangkan babi muda umur sekitar 3 bulan pembelinya umumnya adalah pedagang pengumpul (pengepul), yang selanjutnya akan dijual kembali. Ternak dewasa (celeng) umumnya dijual kepada konsumen (masyarakat) yang membutuhkan babi yang biasanya digunakan untuk keperluan upacara keagamaan. Sebagian besar (65\%) peternak menjual babinya kepada pengepul (40\% melalui penyotek dan $25 \%$ tanpa melalui penyotek).

Hasil pengamatan di lapangan menunjukkan bahwa jumlah pembeli seperti pedagang pengepul jumlahnya sangat sedikit yaitu hanya ada 1-2 pengepul dalam satu desa, sedangkan jumlah peternak sangat banyak. 
Dengan demikian maka peternak menghadapi struktur pasar yang mengarah pada pasar oligopsoni. Hal ini sejalan dengan hasil penelitian Rindayanti dan Cyrilla (2010). Dalam traksaksi jual-beli, pedagang pengepul memiliki peran yang lebih dominan dalam menentukan harga (price maker) sedangkan peternak menjadi penerima harga (price taker). Ini menandakan bahwa posisi tawar peternak sangat lemah.

\section{Perilaku Pasar}

Dalam penelitian ini perilaku pasar dilihat dari kegiatan pembelian, penjualan, penentuan harga, dan siasat pasar untuk memperkuat posisi di dalam pasar. Hasil penelitian ini menunjukkan, bahwa proses pembentukan harga pada peternak produsen di desa dengan pedagang pengumpul (pengepul) yang datang melalui proses tawar menawar, namun demikian pengepul lebih dominan atau mempunyai posisi tawar yang lebih kuat dalam penentuan harga. Sebelum menjual babi peternak biasanya mencari informasi harga dari penyotek, pedagang pengumpul, dan juga dari peternak lainnya yang sebelumnya telah menjual babi. Informasi tersebut digunakan oleh peternak untuk menentukan kepada siapa dan harga berapa mereka harus menjual babinya. Peternak responden pada umumnya tidak mengalami kesulitan dalam memasarkan babinya terutama pada hari-hari menjelang hari raya agama Hindu. Hal ini terjadi karena babi bali banyak dibutuhkan untuk dijadikan sebagai bahan babi guling pelengkap upakara yadnya. Dalam memperoleh babi, para pengepul umumnya mempunyai informan yang ada di desa lokasi peternak yang disebut sebagai penyotek. Penyotek biasanya diberikan imbalan berupa komisi sebesar Rp. 15.000,- per ekor babi yang diperoleh pengepul. Sistem pembayaran yang dilakukan pada umumnya adalah tunai, dimana pembayaran akan dilakukan sebelum babi diambil oleh pengepul. Pengepul dan peternak umumnya memiliki hubungan yang sangat baik dan akrab, sehingga peternak biasanya sudah berlangganan dengan pengepul tertentu. Persaingan yang terjadi di antara pedagang biasanya dalam bentuk harga. Harga yang diberikan oleh pedagang pengepul bervariasi sesuai dengan kualitas babi yang diperjualbelikan. Kualitas tersebut menyangkut kondisi tubuh (gemuk atau kurus). Yang lebih gemuk tentu lebih disukai oleh pembeli sehingga harganya lebih mahal. Siasat pasar yang dilakukan oleh peternak produsen adalah melakukan penjualan kepada pembeli yang menawar dengan harga paling tinggi.

\section{Saluran Pemasaran}

Pemasaran babi bali memiliki beberapa macam saluran. Saluran-saluran tersebut dapat dilihat pada Gambar berikut.

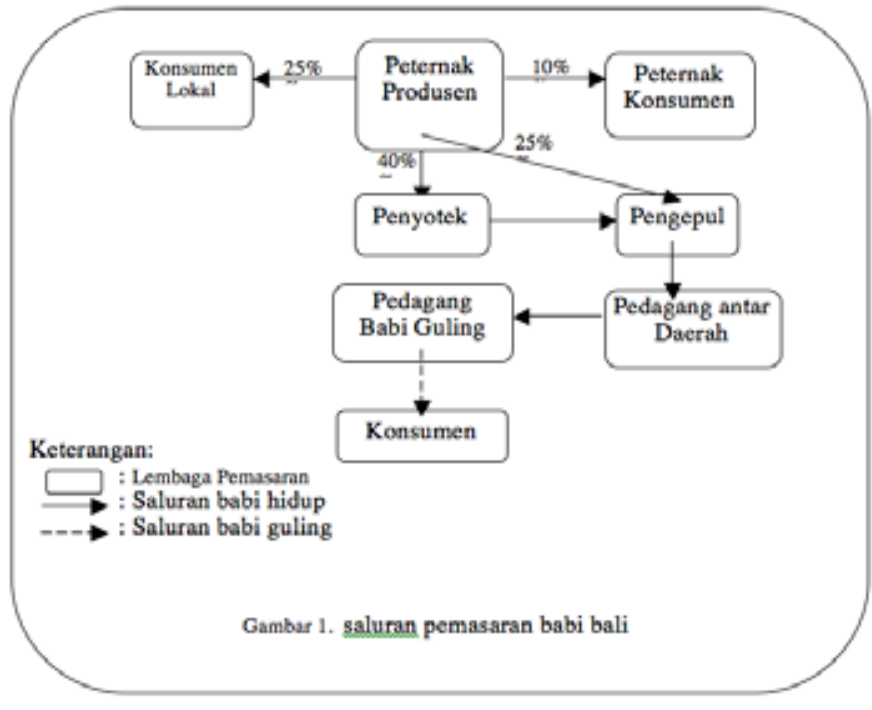

Gambar 1. saluran pemasaran babi bali.

Berdasarkan gambar tersebut di atas, pemasaran babi bali memiliki 4 macam saluran pemasaran yaitu:

1. Peternak $\rightarrow$ Peternak Konsumen

2. Peternak $\rightarrow$ Konsumen Lokal

3. Peternak $\rightarrow$ Pengepul $\rightarrow$ Pedagang Antar Daerah $\rightarrow$

Pedagang Pembuat Babi Guling $\rightarrow$ Konsumen

4. Peternak $\rightarrow$ Penyotek $\rightarrow$ Pengepul $\rightarrow$ Pedagang

Antar Daerah $\rightarrow$ Pedagang Pembuat Babi Guling $\rightarrow$

Konsumen

Berdasarkan gambar di atas, peternak menyalurkan babinya kepada peternak konsumen, konsumen lokal, penyotek, dan pengepul. Peternak konsumen merupakan konsumen yang membeli babi dengan tujuan untuk dipelihara kembali. Sedangkan konsumen lokal merupakan konsumen yang berada disekitar lokasi peternak, yang membeli babi dengan tujuan untuk dipotong. Hasil penelitian ini menunjukkan bahwa sekitar $65 \%$ babi yang dipasarkan oleh peternak dibeli oleh pengepul, baik melalui penyotek (40\%) maupun tanpa melalui penyotek (25\%). Sekitar 10\% babi yang dipasarkan peternak, dibeli langsung oleh peternak konsumen untuk dipelihara kembali, dan sisanya (25\%) dibeli oleh konsumen lokal yang berada disekitar lokasi peternak dengan tujuan untuk dipotong.

\section{Farmer's share, Margin Pemasaran dan Rasio Keuntungan terhadap Biaya}

\section{Analisis pada Saluran Pemasaran 1}

Tabel 1 menunjukkan bahwa pada saluran pemasaran 1, farmer's share (bagian yang diterima peternak dari harga di peternak konsumen) adalah $100 \%$. Ini terjadi karena tidak ada pedagang perantara yang terlibat dalam pemasaran. Melalui saluran ini peternak memperoleh harga jual yang lebih tinggi dibandingkan 
melalui saluran-saluran lainnya. Hal ini terjadi karena babi yang dijual ini adalah babi yang akan dijadikan sebagai bibit sehingga merupakan babi pilihan yang kualitasnya baik, sehingga harganya lebih tinggi.

Rata-rata besarnya keuntungan yang diperoleh peternak melalui saluran ini adalah Rp. 135.556-/ekor, dengan rasio keuntungan terhadap biaya produksi sebesar 24,02\%. Artinya, besarnya keuntungan dari usaha penggemukan babi bali adalah sebesar 24,02\% dari biaya produksi.

Tabel 1. Efisiensi pemasaran babi bali pada saluran pemasaran 1

\begin{tabular}{clrrr}
\hline No & \multicolumn{1}{c}{ Uraian } & Nilai & Satuan & Share (\%) \\
\hline A & Peternak Penggemukan & & & \\
1 & Harga jual & 700.000 & Rp/ekor & 100,00 \\
2 & Biaya & & & \\
& a. Harga Beli Bibit & 400.000 & Rp/ekor & 57,14 \\
& b. Biaya selain bibit & 164.444 & Rp/ekor & 23,49 \\
& Jumlah Biaya & 564.444 & Rp/ekor & 80,63 \\
3 & Margin Pemasaran & 300.000 & Rp/ekor & 42,86 \\
4 & Keuntungan & 135.556 & Rp/ekor & 19,37 \\
4 & Rasio keuntungan terha- & 24,02 & $\%$ & \\
& dap biaya ( $\pi / C)$ & & & \\
B & Peternak Konsumen & & & \\
& Harga Beli & 700.000 & Rp/ekor & 100 \\
\hline
\end{tabular}

Keterangan:

Share (\%); bagian harga dari harga beli konsumen akhir

\section{Analisis pada Saluran Pemasaran 2}

Hasil analisis farmer's share, marjin pemasaran, dan rasio keuntungan terhadap biaya pada saluran pemasaran 2 disajikan pada Tabel 2.

Tabel 2. Efisiensi pemasaran babi bali pada saluran pemasaran 2

\begin{tabular}{clrrr}
\hline No & \multicolumn{1}{c}{ Uraian } & Nilai & Satuan & Share (\%) \\
\hline A & Peternak Penggemukan & & & \\
1 & Harga jual di peternak & 675.000 & Rp/ekor & 100,00 \\
2 & Biaya & & & \\
& a. Harga Beli Bibit & 400.000 & Rp/ekor & 57,14 \\
& b. Biaya selain bibit & 164.444 & Rp/ekor & 23,49 \\
& Jumlah Biaya & 564.444 & Rp/ekor & 80,63 \\
3 & Margin Pemasaran & 275.000 & Rp/ekor & 40,74 \\
4 & Keuntungan & 110.556 & Rp/ekor & 16,38 \\
4 & Rasio keuntungan terhadap & 19,59 & $\%$ & \\
& biaya ( $\pi / C)$ & & & \\
B & Konsumen Lokal & & & \\
& Harga beli & 675.000 & Rp/ekor & 100 \\
\hline
\end{tabular}

Keterangan:

Share (\%); bagian harga dari harga beli konsumen akhir

Share peternak (farmer's share) pada saluran ini adalah $100 \%$. Artinya, melalui saluran pemasaran ini, 100\% dari harga yang dibayarkan oleh konsumen lokal akan menjadi milik peternak produsen. Hal ini terjadi karena konsumen lokal yang membutuhkan babi biasanya datang langsung ke peternak untuk membeli babi. Konsumen lokal tersebut biasanya tinggal di sekitar lokasi peternak. Mereka biasanya membeli babi untuk dipotong sebagai pelengkap upakara yadnya.

Rata-rata besarnya keuntungan yang diperoleh peternak melalui saluran ini adalah Rp. 110.556-/ekor, dengan rasio keuntungan terhadap biaya produksi sebesar 19,59\%. Artinya, besarnya keuntungan dari usaha penggemukan babi bali adalah sebesar 19,59\% dari biaya produksi.

\section{Analisis pada Saluran Pemasaran 3}

Tabel 3 menunjukkan bahwa pada saluran pemasaran 3, farmer's share adalah 40,63\%. Artinya, hanya sekitar 40,63\% dari harga yang dibayarkan oleh konsumen babi guling yang akan diterima peternak penggemukan. Sisanya merupakan margin pemasaran yang dinikmati oleh pedagang perantara.

Pedagang babi guling menikmati margin pemasaran yang paling besar, yaitu sekitar 37,50\% dari harga di konsumen. Sekitar 63,33\% dari jumlah margin tersebut merupakan keuntungan, dan sisanya merupakan biaya pemasaran. Pedagang babi guling menikmati keuntungan yang paling besar diantara lembaga pemasaran. Besarnya keuntungan yang diperoleh oleh pedagang babi guling dari setiap ekor babi guling rata-rata mencapai Rp. 380.000,-. Sedangkan yang dinikmati oleh pengepul Rp. 128.00o,- /ekor dan yang dinikmati oleh pedagang antar daerah mencapaiu 175.000,-/ ekor. Peternak memperoleh keuntungan yang paling kecil, yaitu hanya Rp. 85.556,-/ekor. Rasio keuntungan terhadap biaya antara yang dicapai peternak dengan yang dicapai pedagang perantara pada saluran ini sangat timpang yang menandakan bahwa pemasaran babi bali kurang efisien Rasio keuntungan terhadap biaya yang dicapai oleh pedagang perantara jauh lebih besar dibandingkan dengan yang diperoleh peternak. Rasio keuntungan terhadap biaya yang dicapai pengepul, pedagang antar daerah, dan pedagang babi guling masing-masing berturut-turut sebesar $581,82 \%$, $700 \%$, dan $172,73 \%$.

Hal ini sungguh berbeda dengan rasio keuntungan terhadap biaya yang dicapai oleh peternak, yaitu hanya 15,16\%. Pengepul memperoleh keuntungan sebesar Rp. 581,82,- dari setiap Rp. 100 biaya yang dikeluarkan. Sedangkan peternak hanya memperoleh keuntungan sebesar Rp. 15,16,- dari setiap Rp. 100 biaya yang dikeluarkan.

\section{Analisis pada Saluran Pemasaran 4}

Pada saluran ini, farmer's share adalah 40,63\%, artinya hanya sekitar 40,63\% dari harga yang dibayarkan oleh konsumen babi guling yang akan diterima peternak (Tabel 4). Sisanya merupakan margin pemasaran yang dinikmati oleh pedagang perantara. 
Tabel 3. Efisiensi pemasaran babi bali pada saluran pemasaran 3

\begin{tabular}{|c|c|c|c|c|}
\hline No & Uraian & Nilai & Satuan & Share (\%) \\
\hline A & Peternak & & & \\
\hline 1 & Harga Jual Peternak & 650.000 & Rp/ekor & 40,63 \\
\hline \multirow[t]{4}{*}{2} & Biaya & & & \\
\hline & a. Harga Beli Bibit & 400.000 & Rp/ekor & 25,00 \\
\hline & b. Biaya selain bibit & 164.444 & Rp/ekor & 10,28 \\
\hline & Jumlah Biaya & 564.444 & Rp/ekor & 35,28 \\
\hline 2 & Margin pemasaran & 250.000 & Rp/ekor & 15,63 \\
\hline 3 & Keuntungan & 85.556 & Rp/ekor & 5,35 \\
\hline 4 & $\begin{array}{l}\text { Rasio keuntungan terhadap } \\
\text { biaya }(\pi / C)\end{array}$ & 15,16 & $\%$ & \\
\hline B & Pengepul & & & \\
\hline 1 & Harga jual pengepul & 800.000 & Rp/ekor & 50,00 \\
\hline \multirow[t]{6}{*}{2} & Biaya Pemasaran & & & \\
\hline & Transportasi & 2.000 & Rp/ekor & 0,13 \\
\hline & $\begin{array}{l}\text { Biaya pemeliharaan saat } \\
\text { penampungan }\end{array}$ & 10.000 & Rp/ekor & 0,63 \\
\hline & Upah Tenaga kerja & 5.000 & Rp/ekor & 0,31 \\
\hline & Telp & 5.000 & Rp/ekor & 0,31 \\
\hline & Jumlah Biaya Pemasaran & 22.000 & Rp/ekor & 1,38 \\
\hline 3 & Margin Pemasaran & 150.000 & Rp/ekor & 9,38 \\
\hline 4 & Keuntungan pemasaran & 128.000 & Rp/ekor & 8,00 \\
\hline 5 & $\begin{array}{l}\text { Rasio keuntungan terhadap } \\
\text { biaya }(\pi / C)\end{array}$ & 581,82 & $\%$ & 0,04 \\
\hline $\mathrm{C}$ & Pedagang Antar daerah & & & \\
\hline 1 & $\begin{array}{l}\text { Harga jual pedagang Antar } \\
\text { Daerah }\end{array}$ & 1.000 .000 & Rp/ekor & 62,50 \\
\hline \multirow[t]{5}{*}{2} & Biaya Pemasaran & & & \\
\hline & Transportasi & 10.000 & Rp/ekor & 0,63 \\
\hline & Upah tenaga/anak buah & 10.000 & Rp/ekor & 0,63 \\
\hline & Komunikasi/telp & 5.000 & Rp/ekor & 0,31 \\
\hline & Jumlah Biaya Pemasaran & 25.000 & Rp/ekor & 1,56 \\
\hline 3 & Margin Pemasaran & 200.000 & Rp/ekor & 12,50 \\
\hline 4 & Keuntungan pemasaran & 175.000 & Rp/ekor & 10,94 \\
\hline 5 & $\begin{array}{l}\text { Rasio keuntungan terhadap } \\
\text { biaya }(\pi / C)\end{array}$ & 700,00 & $\%$ & 0,04 \\
\hline D & Pedagang Babi Guling & & & \\
\hline 1 & $\begin{array}{l}\text { Harga jual Pedagang Babi } \\
\text { Guling }\end{array}$ & 1.600 .000 & Rp/ekor & 100,00 \\
\hline \multirow[t]{10}{*}{2} & Biaya Pemasaran & & & \\
\hline & $\begin{array}{l}\text { Pemeliharaan di Penam- } \\
\text { pungan }\end{array}$ & 10.000 & Rp/ekor & 0,63 \\
\hline & $\begin{array}{l}\text { Biaya pembuatan babi } \\
\text { guling }\end{array}$ & & & \\
\hline & a. Tenaga kerja & 100.000 & Rp/ekor & 6,25 \\
\hline & b. Bumbu & 50.000 & Rp/ekor & 3,13 \\
\hline & c. Kayu bakar & 30.000 & Rp/ekor & 1,88 \\
\hline & d. Konsumsi tenaga & 15.000 & Rp/ekor & 0,94 \\
\hline & e. Penyusutan & 10.000 & Rp/ekor & 0,63 \\
\hline & f. Transportasi & 5.000 & Rp/ekor & 0,31 \\
\hline & Jumlah Biaya Pemasaran & 220.000 & Rp/ekor & 13,75 \\
\hline 3 & Margin Pemasaran & 600.000 & Rp/ekor & 37,50 \\
\hline 4 & Keuntungan pemasaran & 380.000 & Rp/ekor & 23,75 \\
\hline 5 & $\begin{array}{l}\text { Rasio keuntungan terhadap } \\
\text { biaya }(\pi / \mathrm{C})\end{array}$ & 172,73 & $\%$ & \\
\hline
\end{tabular}

Keterangan:

Share (\%); bagian harga dari harga beli konsumen akhir
Tabel 4. Efisiensi pemasaran babi bali pada saluran pemasaran 4

\begin{tabular}{|c|c|c|c|c|}
\hline No & Uraian & Nilai & Satuan & Share (\%) \\
\hline A & Peternak & & & \\
\hline 1 & Harga Jual Peternak & 650.000 & Rp/ekor & 40,63 \\
\hline \multirow[t]{4}{*}{2} & Biaya & & & \\
\hline & a. Harga Beli Bibit & 400.000 & Rp/ekor & 25,00 \\
\hline & b. Biaya selain bibit & 164.444 & Rp/ekor & 10,28 \\
\hline & Jumlah Biaya & 564.444 & Rp/ekor & 35,28 \\
\hline 3 & Margin pemasaran & 250.000 & Rp/ekor & 15,63 \\
\hline 4 & Keuntungan & 85.556 & Rp/ekor & 5,35 \\
\hline 5 & $\begin{array}{l}\text { Rasio keuntungan terhadap } \\
\text { biaya }(\pi / C)\end{array}$ & 15,16 & $\%$ & \\
\hline B & Penyotek & & & \\
\hline 1 & Harga jual & 665.000 & Rp/ekor & 41,56 \\
\hline \multirow[t]{4}{*}{2} & Biaya & & & \\
\hline & a. Transportasi & 1.000 & Rp/ekor & 0,06 \\
\hline & b. Telepon & 1.000 & Rp/ekor & 0,06 \\
\hline & Jumlah Biaya & 2.000 & Rp/ekor & 0,13 \\
\hline 3 & Margin pemasaran & 15.000 & Rp/ekor & 0,94 \\
\hline 4 & Keuntungan & 13.000 & Rp/ekor & 0,81 \\
\hline 5 & $\begin{array}{l}\text { Rasio keuntungan terhadap } \\
\text { biaya }(\pi / C)\end{array}$ & 650,00 & $\%$ & \\
\hline $\mathrm{C}$ & Pengepul & & & \\
\hline 1 & Harga jual pengepul & 800.000 & Rp/ekor & 50,00 \\
\hline \multirow[t]{7}{*}{2} & Biaya Pemasaran & & & \\
\hline & a. Transportasi & 2.000 & Rp/ekor & 0,13 \\
\hline & b. Komisi untuk penyotek & 15.000 & Rp/ekor & 0,94 \\
\hline & c. Upah Tenaga kerja & 5.000 & Rp/ekor & 0,31 \\
\hline & $\begin{array}{l}\text { d. Biaya pemeliharaan saat } \\
\text { penampungan }\end{array}$ & 10.000 & Rp/ekor & 0,63 \\
\hline & e. Telp & 5.000 & Rp/ekor & 0,31 \\
\hline & Jumlah Biaya Pemasaran & 37.000 & Rp/ekor & 2,31 \\
\hline 3 & Margin Pemasaran & 150.000 & Rp/ekor & 9,38 \\
\hline 4 & Keuntungan pemasaran & 113.000 & Rp/ekor & 7,06 \\
\hline 5 & $\begin{array}{l}\text { Rasio keuntungan terhadap } \\
\text { biaya }(\pi / C)\end{array}$ & 305,41 & $\%$ & 0,02 \\
\hline $\mathrm{D}$ & Pedagang Antar daerah & & & \\
\hline 1 & $\begin{array}{l}\text { Harga jual pedagang Antar } \\
\text { Daerah }\end{array}$ & 1.000 .000 & Rp/ekor & 62,50 \\
\hline \multirow[t]{5}{*}{2} & Biaya Pemasaran & & & \\
\hline & a. Transportasi & 10.000 & Rp/ekor & 0,63 \\
\hline & b. Komunikasi/telp & 5.000 & Rp/ekor & 0,31 \\
\hline & c. Upah tenaga/anak buah & 10.000 & Rp/ekor & 0,63 \\
\hline & Jumlah Biaya Pemasaran & 25.000 & Rp/ekor & 1,56 \\
\hline 3 & Margin Pemasaran & 200.000 & Rp/ekor & 12,50 \\
\hline 4 & Keuntungan pemasaran & 175.000 & Rp/ekor & 10,94 \\
\hline 5 & $\begin{array}{l}\text { Rasio keuntungan terhadap } \\
\text { biaya }(\pi / C)\end{array}$ & 700,00 & $\%$ & 0,04 \\
\hline $\mathrm{E}$ & Pedagang Babi Guling & & & \\
\hline 1 & $\begin{array}{l}\text { Harga jual Pedagang Babi } \\
\text { Guling }\end{array}$ & 1.600 .000 & Rp/ekor & 100,00 \\
\hline \multirow[t]{10}{*}{2} & Biaya Pemasaran & & & \\
\hline & $\begin{array}{l}\text { Pemeliharaan di Penam- } \\
\text { pungan }\end{array}$ & 10.000 & Rp/ekor & 0,63 \\
\hline & $\begin{array}{l}\text { Biaya pembuatan babi } \\
\text { guling }\end{array}$ & & & \\
\hline & a. Tenaga kerja & 100.000 & Rp/ekor & 6,25 \\
\hline & b. Bumbu & 50.000 & Rp/ekor & 3,13 \\
\hline & c. Kayu bakar & 30.000 & Rp/ekor & 1,88 \\
\hline & d. Konsumsi tenaga kerja & 15.000 & Rp/ekor & 0,94 \\
\hline & e. Penyusutan & 10.000 & Rp/ekor & 0,63 \\
\hline & f. Transportasi & 5.000 & Rp/ekor & 0,31 \\
\hline & Jumlah Biaya Pemasaran & 220.000 & Rp/ekor & 13,75 \\
\hline 3 & Margin Pemasaran & 600.000 & Rp/ekor & 37,50 \\
\hline 4 & Keuntungan pemasaran & 380.000 & Rp/ekor & 23,75 \\
\hline 5 & $\begin{array}{l}\text { Rasio keuntungan terhadap } \\
\text { biaya }(\pi / \mathrm{C})\end{array}$ & 172,73 & $\%$ & \\
\hline
\end{tabular}

Keterangan:

Share (\%); bagian harga dari harga beli konsumen akhir 
Pedagang babi guling menikmati margin pemasaran yang paling besar, yaitu sekitar $37,50 \%$ dari harga di konsumen. Sekitar $63,33 \%$ dari jumlah margin tersebut merupakan keuntungan, dan sisanya merupakan biaya pemasaran. Pedagang babi guling menikmati keuntungan yang paling besar diantara lembaga pemasaran. Besarnya keuntungan yang diperoleh oleh pedagang babi guling dari setiap ekor babi guling rata-rata mencapai Rp. 380.00o,-. Sedangkan yang dinikmati oleh penyotek Rp 13.000,-/ekor, pengepul Rp. 113.00o,- /ekor dan yang dinikmati oleh pedagang antar daerah mencapai 175.000,-/ekor. Peternak memperoleh keuntungan yang lebih kecil dibandingkan pengepul, pedagang antar daerah maupun pedagang babi guling, yaitu hanya Rp. 85.556,-/ekor. Rasio keuntungan terhadap biaya antara yang dicapai peternak dengan yang dicapai pedagang perantara pada saluran ini sangat timpang yang menandakan bahwa pemasaran babi bali kurang efisien.

Rasio keuntungan terhadap biaya yang dicapai oleh pedagang perantara jauh lebih besar dibandingkan dengan peternak. Rasio keuntungan terhadap biaya yang dicapai pengepul, pedagang antar daerah, dan pedagang babi guling berturut-turut sebesar 305,41\%, $700 \%$, dan $172,73 \%$. Hal ini sungguh berbeda dengan rasio keuntungan terhadap biaya yang dicapai oleh peternak, yaitu hanya $15,16 \%$. Pengepul memperoleh keuntungan sebesar Rp. 305,41,- dari setiap Rp. 100 biaya yang dikeluarkan. Sedangkan peternak hanya memperoleh keuntungan sebesar Rp.15,16,- dari setiap Rp. 100 biaya yang dikeluarkan.

\section{SIMPULAN}

Pemasaran babi bali yang dihasilkan oleh peternak kurang efisien yang ditunjukkan oleh farmer's share yang rendah, margin pemasaran diantara lembagalembaga pemasaran yang kurang merata, rasio keuntungan terhadap biaya yang dicapai lembagalembaga pemasaran sangat timpang dibandingkan dengan yang dicapai peternak.

\section{DAFTAR PUSTAKA}

Aditya, P.N. 2006. Analisis Efisiensi saluran pemasaran jamur tiram segar di Bogor, Propinsi Jawa Barat.

Daniel, M. 2004. Pengantar Ekonomi Pertanian.PT. Bumi Aksara. Jakarta.

Budaarsa, K. 2012. Babi Guling Bali. Penerbit Buku Arti. Denpasar

Budaarsa, K. 2014. Potensi Ternak Babi dalam Pemenuhan Daging di Bali. Prosiding Seminar dan Lokakarya Nasional Ternak Babi. Fakultas Peternakan, Universitas Udayana. Denpasar.

Budaarsa, K. 1997. Kajian Penggunaan Rumput Lautdan Sekam Padi sebagai Sumber Serat dalam Ransum untuk Menurunkan Kadar Lemak Karkas dan Kolesterol Daging Babi. Disertasi. Program Pascasarjana Institut Pertanian Bogor. Bogor.

Jumiati, E., D. H. Darwanto, S. Hartono, dan Masyhuri. 2013 Analisis Saluran Pemasaran dan Marjin Pemasaran Kelapa Dalam di Daerah Perbatasan Kalimantan Timur. Jurnal AGRIFOR. Vol 12, No. 1, Tahun 2013. P: 1-10.

Rindayanti, W. dan L. Cyrilla. 2010. Analisis efisiensi pemasaran ternak potong sapi madura di Kabupaten Pamekasan. Media Peternakan, Vol. 24, No. 1. Tahun 2010, P:81-86.

Sutarno. 2014. Analisis Efisiensi Pemasaran Kedelai di Kabupaten Wonogiri. e-Journal Agrineca. Vol. 14, No. 1, Tahun 2014. P: 1-10.

Wibawa, I M. S.P., K Budaarsa, dan I G. Mahardika. Performans dan Komposisi Karkas Babi Bali Betina Muda yang Diberi Ransum dengan Suplementasi Probiotik. Majalah Ilmiah Peternakan. Vol. 22, No. 2. Tahun 2019. P: 43-49. 